\title{
Modelling of masonry infill walls participation in the seismic behaviour of RC buildings using OpenSees
}

\author{
André Furtado $^{1} \cdot$ Hugo Rodrigues ${ }^{2} \cdot$ António Arêde ${ }^{1}$
}

Received: 18 July 2014/ Accepted: 30 March 2015/Published online: 15 April 2015

(c) The Author(s) 2015. This article is published with open access at Springerlink.com

\begin{abstract}
Recent earthquakes show that masonry infill walls should be taken into account during the design and assessment process of structures, since this type of nonstructural elements increase the in-plane stiffness of the structure and consequently the natural period. An overview of the past researches conducted on the modelling of masonry infilled frame issues has been done, with discussion of past analytical investigations and different modelling approaches that many authors have proposed, including micro- and macro-modelling strategies. After this, the present work presents an improved numerical model, based on the Rodrigues et al. (J Earthq Eng 14:390-416, 2010) approach, for simulating the masonry infill walls behaviour in the computer program OpenSees. The main results of the in-plane calibration analyses obtained with one experimental test are presented and discussed. For last, two reinforced concrete regular buildings were studied and subjected to several ground motions, with and without infills' walls.
\end{abstract}

Keywords Masonry infill walls - In-plane behaviour . Regular RC buildings · Vulnerability

Hugo Rodrigues

hugo.f.rodrigues@ipleiria.pt

1 Faculdade de Engenharia da Universidade do Porto, Porto, Portugal

2 ESTG, Instituto Politécnico de Leiria, Leiria, Portugal

\section{Introduction}

The presence of masonry infill walls in reinforced concrete (RC) buildings is very common; however, and even today, during the design process of new buildings and in the assessment of existing ones, infills are usually considered to be non-structural elements, and their influence on the structural response is ignored. Their influence is recognized in the global behaviour of RC frames subjected to earthquake loadings (Asteris and Cotsovos 2012; Crisafulli 1997b; Davis et al. 2004; Kakaletsis and Karayannis 2008; Manfredi et al. 2012; Mosalam et al. 1997).

Over the last years, many authors have studied the effects of the infill panels on the response of RC structures and the need of inclusion of these non-structural elements on the structural seismic assessment and design process is recognized. Observations made by technicians and experts to damaged buildings caused by seismic actions (Fig. 1a) proved that the presence of masonry infill walls can have beneficial or negative effects to the structure. The negative effects are associated with plan or vertical irregularities introduced by the infill panels (Varum 2003a), potentially causing different types of mechanisms such as the softstorey mechanism (Fig. 1b) (Furtado et al. 2014) or shortcolumn mechanism (Dolsek and Fajfar 2001; Furtado 2013). The presence of the infills is commonly associated with the significant increase in the overall structural stiffness implied by the infills, and then, a higher natural frequency of vibration, which depends on the relevant seismic spectrum, can lead to an increase in seismic forces.

The large in-plane shear demands that masonry infill walls are subjected to are likely to increase their out-ofplane vulnerability. The associated collapse can result in serious human and material consequences as observed in recent earthquakes (Fig. 1c). The full knowledge of all the 




(a)



(b)

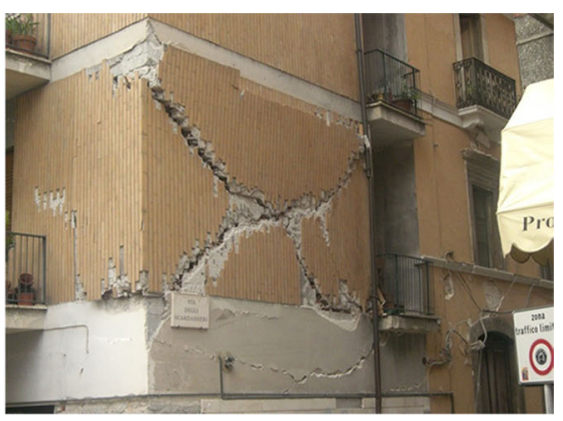

(c)

Fig. 1 a Infill walls collapse (Romão et al. 2013), b soft-storey mechanism (Costa et al. 2010) and c out-of-plane and in-plane damage mechanisms in exterior masonry walls (Romão et al. 2013)

components (structural and non-structural elements) is fundamental to help and guide the designers during the assessment and strengthening process of existing buildings with the main goal of reducing their seismic vulnerability.

The main objective of this work is to present a numerical tool to represent the masonry infills' in-plane behaviour in the computer program OpenSees (Mckenna et al. 2000), based on the model developed by Rodrigues et al. (2010). The in-plane calibration was performed based on the experimental test performed by Pires (1990) in LNEC (Civil Engineering National Laboratory, in Portuguese). After this, two RC buildings with infill panels with equal bay-size dimension but different number of storeys and different disposition of the infill panels were studied, in order to evaluate the effect of the infills' presence in their structural response when subjected to seismic actions.

\section{Background on masonry infill wall modelling approaches}

In the literature, different modelling proposal techniques that simulate the behaviour of the infills' panels can be found and are divided in two different groups, namely micro-models and simplified macro-models. The first of them involves models in which the panel is divided into numerous elements taking into account the local effects in detail, and the second includes simplified models based on the physical understanding of the behaviour of the infills' panels submitted to earthquakes loadings and past experimental tests. In the case of the last group, a few number of struts are used to represent the effect of this non-structural element on the structural response.

\section{Micro-modelling}

The micro-modelling approach considers the effect of the mortar joints as discrete element in the model. Considering

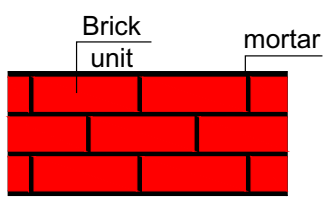

(a)

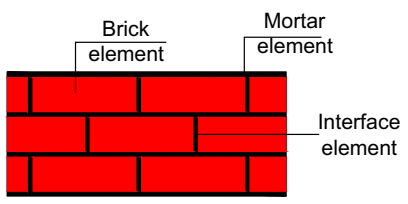

(b)
Fig. 2 a Masonry infill wall sample, b detailed micro-modelling strategy

the fact of mortar joints are the weakest plane in a masonry infill wall, this approach can be considered the most exact. According to Lourenço (2002) and Asteris and Tzamtzis (2003), the micro-modelling procedures can be summarized in two different refinements for masonry walls: simplified micro-modelling where the expanded units are represent by continuum elements and the properties of the mortar and the brick-mortar interface are lumped into a common element (Fig. 2a) and detailed micro-modelling (Fig. 2b) where brick units and the mortar are represented by continuum elements and the brick units-mortar interaction are represent by different continuum elements, which leads to accurate results and intensive computational requirement (Asteris et al. 2013).

Mallick and Severn (1968) started in 1967 to apply the finite-element method for modelling infilled frame structures. Depending on the composite characteristics of the infilled frames, different elements are required in the model as for example beam or continuum elements for the surrounding frame, continuous elements for the infill panels and interface elements for representing the interaction between the frame and the panel. The main advantage of the micro-modelling is that the infilled frames' in-plane behaviour takes into account with the local effects related to cracking, crushing and contact interaction.

Dhanasekar and Page (1986) proposed 1D joint element to model the separation and shear failure of the joint, and the wall was modelled homogenously. They used the results of 186 half-scale square panels to define the infill 
panel nonlinear material properties. Lofti and Shing studied in 1991 the efficiency of homogenous smeared-crack models to capture the response of reinforced masonry wall, and they showed that the smeared-crack model can accurately capture the flexural failure of the reinforced masonry wall (Lofti and Shing 1991). Mehrabi and Shing (1997) proposed a simplified micro-modelling model that simulated the cracking, crushing and sliding of masonry panel for cyclic and monotonic response. Lourenço and Rots (1997) developed in 1997 an elasto-plastic constitutive model for interface element which shows the ability to capture the peak load and post-peak behaviour of the infill panel when compared to experimental results.

Oliveira and Lourenço (2004) developed a constitutive model based on the earlier interface element to simulate the cyclic behaviour of the interface element recurring to 8 -node continuum plane stress element to model the masonry units. Most recently, Stavridis and Shing (2010) and Koutromanos et al. (2011) proposed different micro-modelling approaches, and another couple of micro-modelling approaches can be found at Asteris et al. (2013).

\section{Macro-modelling}

The masonry infill walls can be analysed through simplified macro-models that use different strategies, ranging from very simple models such as the equivalent strut model to much more complex models like the double- and triplestrut model as illustrated in Fig. 3a-c, respectively (Crisafulli 1997a).

Polyakov (1960) suggested the possibility of considering the effect of modelling the infills as equivalent to one diagonal strut, which was later modified by Holmes (1961) that replaced the infill panel with an equivalent pin-jointed diagonal strut made of the same material and having the same thickness of the masonry infill wall. Later, Smith (1962) based on the experimental tests found the need of introducing new required parameters to modelling the infills. Mainstone and Weeks (1970) and Mainstone (1974) proposed methods for calculating the effective diagonal strut width based on experimental tests.

Klingler and Bertero (1978) considered the nonlinear behaviour of the masonry infill wall when submitted to dynamic loadings, and Liauw and Kwan (1984) developed a semiempirical equation to compute the strut width as a function of other geometrical parameters of the panel. Zarnic and Tomazevic (1988) proposed a macro-model that takes into account the strength and stiffness of the infills. Saneinejad and Hobbs (1995) tried to predict their nonlinear behaviour through a numerical model that represents the stiffness and strength degradation of one infill panel. Zarnic and Gostic (1997b) proposed an empirical equation, which was later modified by Dolsek and Fajfar (2002) to compute the shear ultimate strength of the masonry infill wall. Dolsek and Fajfar (2002) also defined a tri-linear response of the single-strut model, including an elastic, hardening and post-capping branch. Flanagan and Bennet (1999) focused on the modelling of the corner crushing strength and stiffness of the infills.

Later, through the obtained results it becomes clear that using only one single strut was insufficient to model the entire behaviour of the infill panel. The shear forces and the bending moment in the frame members cannot be adequately given using one single strut connected to the two loaded corners. Different complex macro-models were proposed based on the number of diagonal struts which has the main advantage of representing the real behaviour of the infill panel when submitted to seismic actions.

Syrmakesis and Vratsanou (1986) changed this strut model to a five-diagonal strut model that can model the global force-displacement response but otherwise is not able to capture the interaction between infill panel and the surrounding frame. Schmidt (1989) proposed a double strut that takes into account with the frame-infill interaction and also the strength and stiffness of the panel. Chrystomou (1991) increases the number of struts in order to represent the infill panel response with three parallel struts in which direction.

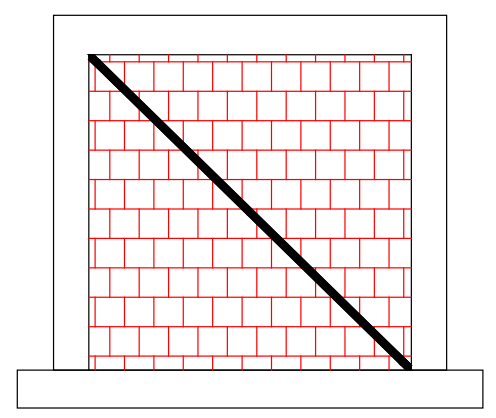

(a)

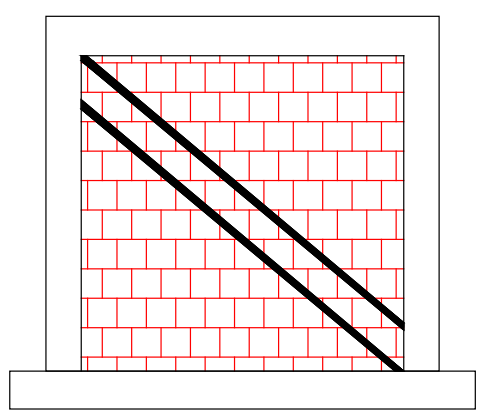

(b)

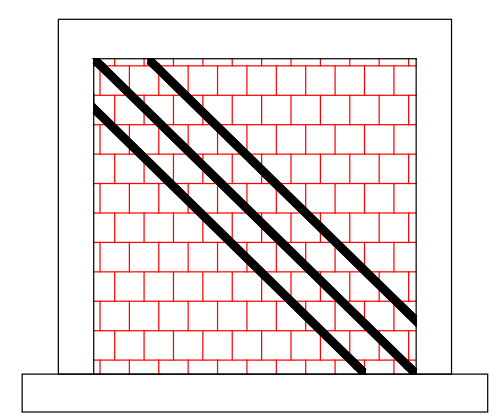

(c)

Fig. 3 Different macro-modelling strategies. a Single-strut model, b double-strut model and $\mathbf{c}$ triple-strut model 
Crisafully (1997a) investigated the influence of different multi-strut models on the structural response of masonry infill walls, focusing in particular on the interaction with surrounding frames and the stiffness of the structure. Crisafulli (Smyrou et al. 2011) adopted a double-strut model approach that is accurate enough and less complicated than other models.

El-Dakhakhni et al. (2003) developed a model with three non-parallel struts to reproduce the proper moment diagram of the columns in an infilled due to the interaction between infill and the surrounding frame and also to adequately capture the corner crushing failure mechanism.

Crisafulli and Carr (2007) proposed a new macro-model as a four-node panel, which is connected to the frame at the beam-column joints and is composed of two parallel struts and a shear spring in each direction, takes into account the compressive and shear behaviour of the infill panel.

Recently, Rodrigues et al. (Rodrigues 2005) proposed a simplified macro-model which is an upgrading of the equivalent bi-diagonal compression strut model (as shown in Fig. 4), commonly used to simulate the nonlinear behaviour of infill masonry panels subjected to cyclic loads and validate with experimental results obtained. Each masonry panel is structurally defined by four support strut elements with rigid behaviour and one central strut element, where the nonlinear hysteretic behaviour is concentrated (Fig. 4). This particular macro-model considers how the in-plane damage in one direction affects the infills'

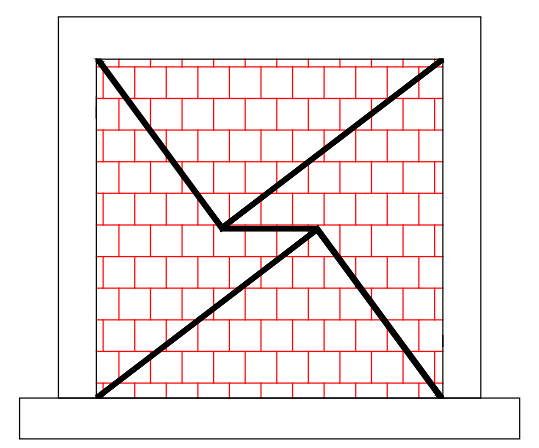

Fig. 4 Rodrigues et al.’s simplified macro-model (Rodrigues 2005) behaviour in the other direction. Therefore, the proposed model represents more accurately the global response and energy dissipation during structural response.

\section{Proposed procedure for masonry infill wall modelling in OpenSees}

The macro-model proposed here to be used in the computer program OpenSees (Mckenna et al. 2000) is based on the Rodrigues et al. (2010) proposal model which is an improvement of the commonly used equivalent bi-diagonal strut model, as said before. This simplified macro-model does not take into account the short-column effects. For infilled frames where the short-column effect can be induced, multiple-strut model strategy should be adopted.

In this model (Rodrigues et al. 2010), each infill panel is defined by considering four support strut elements, with rigid in-plane behaviour, and a central element, where the in-plane nonlinear hysteretic behaviour is concentrated, as illustrated in Fig. 5a, b. The forces developed in the central element are purely of tensile or compressive nature when submitted to in-plane solicitations. The idealization of the central element nonlinear monotonic behaviour was characterized by a multi-linear curve, defined by eight parameters (Fig. 5c), representing: (a) cracking (cracking force $F_{\mathrm{c}}$ and cracking $d_{\mathrm{c}}$ ); (b) yielding (yielding force $F_{\mathrm{y}}$ and yielding displacement $d_{\mathrm{y}}$ ); (c) maximum strength, corresponding to the beginning of crushing ( $F_{\max }$ and corresponding displacement $d_{\max }$ ); (d) residual strength $\left(F_{\mathrm{u}}\right)$ and corresponding displacement $\left(d_{\mathrm{u}}\right)$. The hysteretic rules calibrated for infills' models are controlled by three additional parameters such: stiffness degradation- $\alpha$, pinching effect $-\beta$ and strength degradation $-\gamma$.

The proposed macro-model for masonry infill walls was implemented in OpenSees (Mckenna et al. 2000) with the association of the available OpenSees materials, sections and elements commands. The infill model is composed of four elastic beam columns for the diagonal elements and one nonlinear beam column for the central element. The Pinching 4 uniaxial material model (Fig. 6) was used to

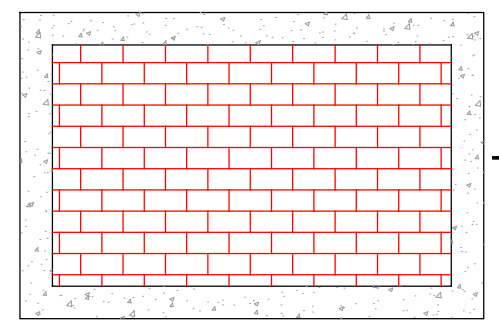

(a)

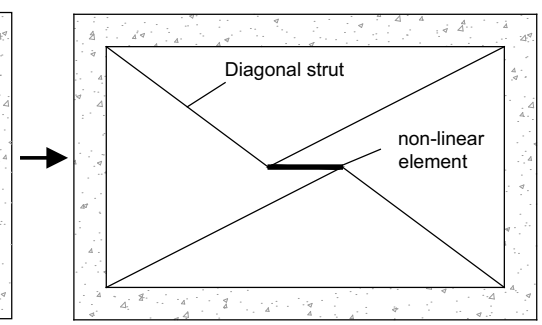

(b)

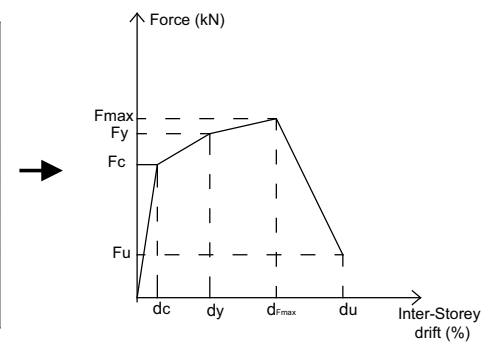

(c)

Fig. 5 a Macro-model, b hysteretic material behaviour for the simulation of a masonry infill panel (adapted by Rodrigues et al. 2010) 
represent the hysteretic rule and was calibrated with experimental characteristics of the infills.

This uniaxial material is adopted to represents a "pinched" load-deformation response which exhibits degradation under cyclic loading. The strength and stiffness cyclic degradation occur in three ways: unloading stiffness degradation, reloading stiffness degradation and strength degradation.

The parameters required to define this uniaxial material hysteric behaviour can be obtained following different authors and international codes recommendations. Previous tests performed by different authors showed that the first crack appears to drift values between 0.05 and $0.15 \%$ of drift $\left(d_{\mathrm{c}}\right)$, and the respective cracking force $\left(F_{\mathrm{c}}\right)$ can be determined through the relationship between $d_{\mathrm{c}}$ and $E_{\mathrm{m}}$, which is the elasticity modulus of the infill panel.

Manzouri (1995) and Shing et al. (2009) found that the maximum strength $\left(F_{\text {cr }}\right)$ occurs at approximately $0.25 \%$ of drift $\left(d_{\mathrm{cr}}\right)$. The maximum strength can be calculated through Eq. (1) proposed by Zarnic and Gornic (1997a) and later modified by Dolsek and Fajfar (2008) where $f_{t p}$ is the

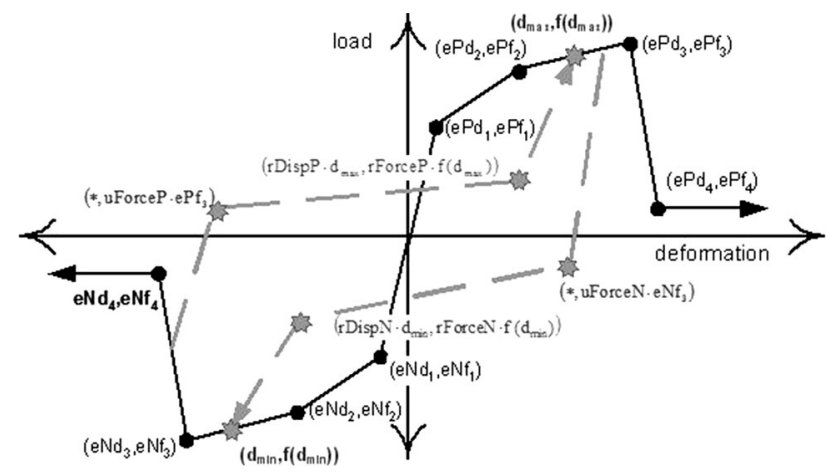

Fig. 6 Pinching 4 uniaxial material—generic hysteretic behaviour in OpenSees (Mckenna et al. 2000) masonry crack stress obtained based on experimental tests; the $t, L_{\text {in }}$ and $h^{\prime}$ are the thickness, length and height of the panel, respectively.

$F_{\max }=0.818 \frac{L_{\text {in }} \times t \times f_{t p}}{C_{\mathrm{I}}}\left(1+\sqrt{C_{\mathrm{I}}^{2}+1}\right)$

$C_{\mathrm{I}}=1.925 \frac{L_{\text {in }}}{h^{\prime}}$

The ratio of cracking and maximum strength $\left(F_{\mathrm{y}} / F_{\mathrm{cr}}\right)$ is adopted as 0.55 following Dolsek and Fajfar (2008) recommendations and the experimental tests performed by Manzouri (1995).

The post-peak strength degradation is based on Dolsek and Fajfar (2008) that estimate the displacement at residual strength $\left(d_{\mathrm{u}}\right)$ is five times of the displacement of maximum stress. The value of the residual strength is about $20 \%$ of the maximum strength $\left(F_{\mathrm{u}}\right)$.

\section{Calibration of the proposed model}

The proposed macro-model presented here to represent the masonry infill walls in OpenSees (Mckenna et al. 2000) was calibrated the results of a cyclic in-plane test performed by Pires (1990). The infilled RC is a single bay, scaled 2:3 with hollow clay bricks. The geometric characteristics of the frame, the cross section dimensions and the reinforcement detailing of the columns and beam are presented in Fig. 7.

The axial load was applied on the top of the columns to simulate the dead load, and imposed cyclic horizontal displacements were applied. The mechanical properties of each material are determined experimentally and are presented in Table 1. Additional information about the material properties and the materials experimental tests can be found in Pires (1990)

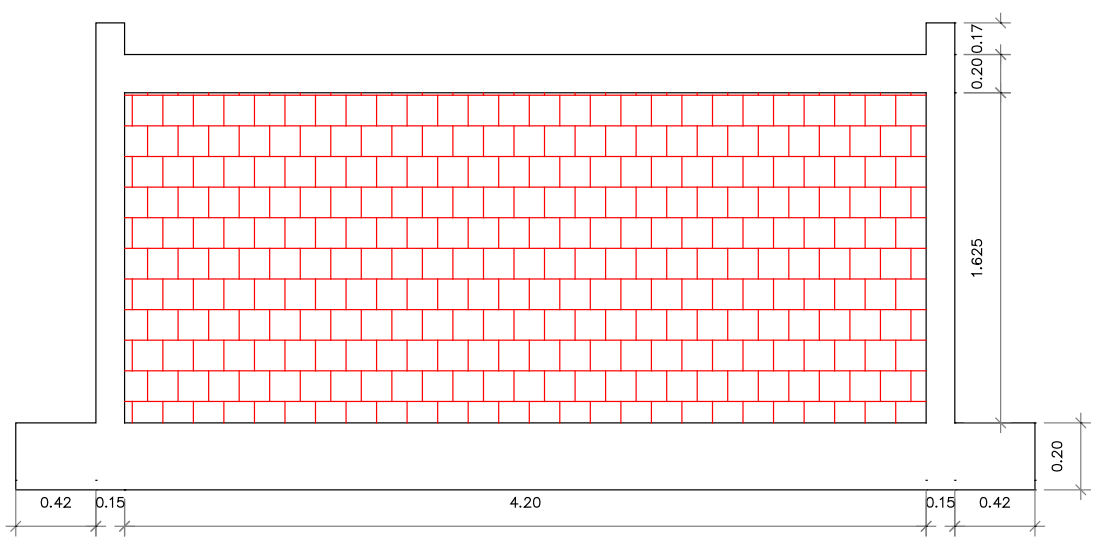

(a)

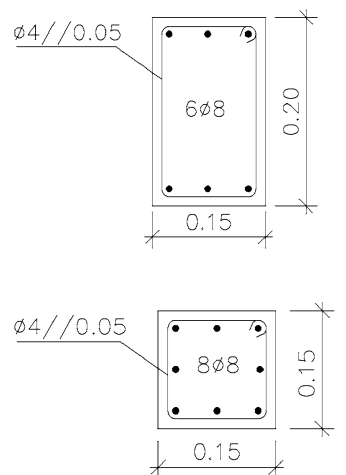

(b)

Fig. 7 Single-storey single-bay infilled masonry RC frame: a frame geometry. b Cross section dimensions and detailing of RC elements 
Table 1 Mechanical properties of the constituent materials from Pires experimental test (Pires 1990)

\begin{tabular}{llr}
\hline Material & Material property & Value $(\mathrm{kPa})$ \\
\hline Masonry wallets & Shear compression $f_{\mathrm{v} 0}$ & 440 \\
& Distortion modulus G & 930,000 \\
& Compression strength $f_{\mathrm{c}}$ & 2200 \\
& Diagonal compression strength $f_{\mathrm{m}}$ & 1100 \\
& Elasticity modulus $E_{\mathrm{m}}$ & $3,119,000$ \\
& Tensile strength $\tau_{0}$ & 270 \\
Concrete compressive strength $f_{\mathrm{c}}$ & 25,300 \\
& Concrete elasticity modulus $E_{\mathrm{c}}$ & $30,000,000$ \\
& Steel reinforcement yield strength $f_{\mathrm{y}}$ & 434,000 \\
& Steel reinforcement elasticity modulus $E_{\mathrm{y}}$ & $190,000,000$ \\
\hline
\end{tabular}

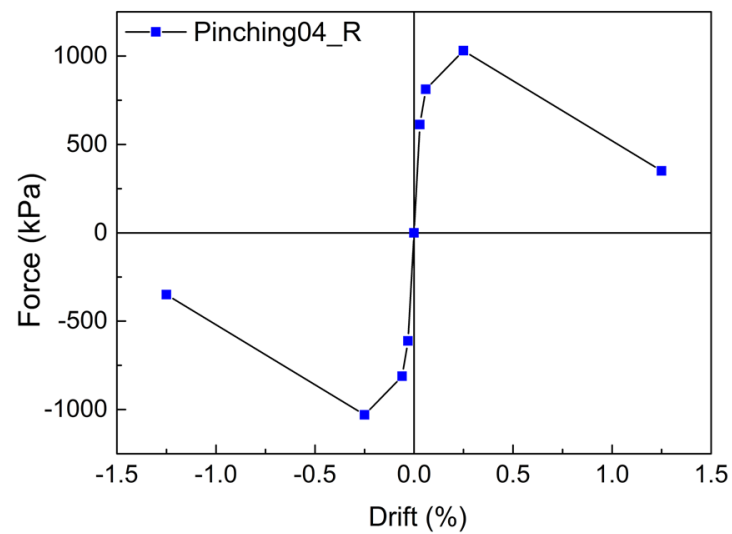

(a)

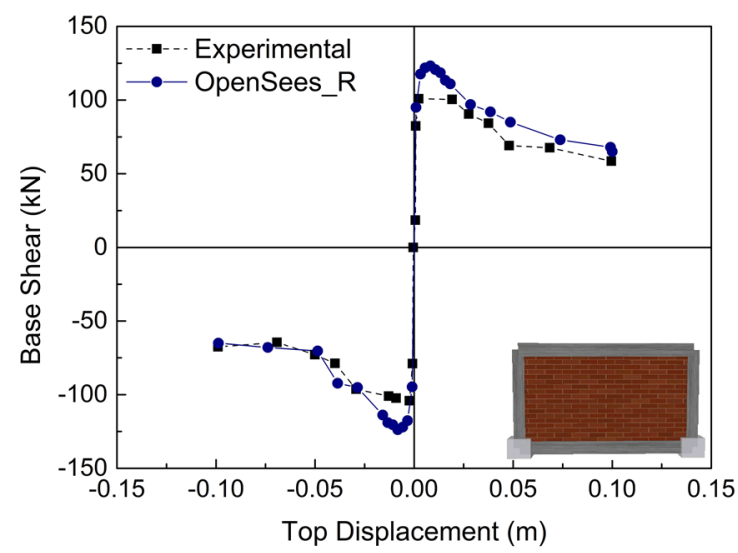

(c)

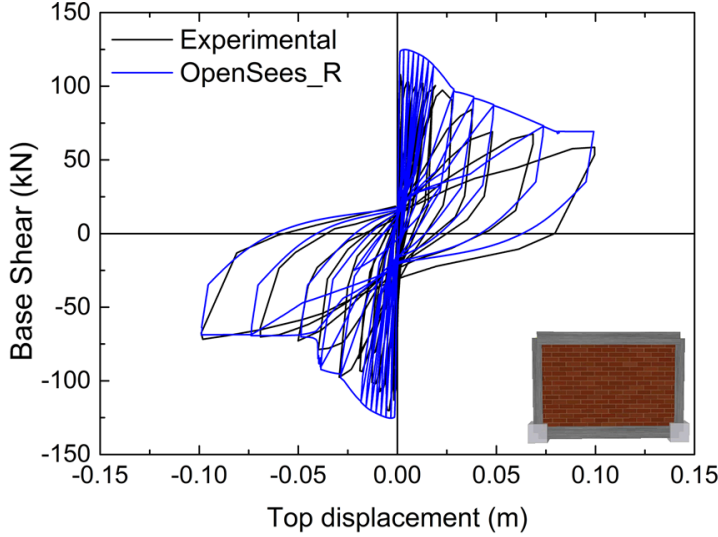

(b)

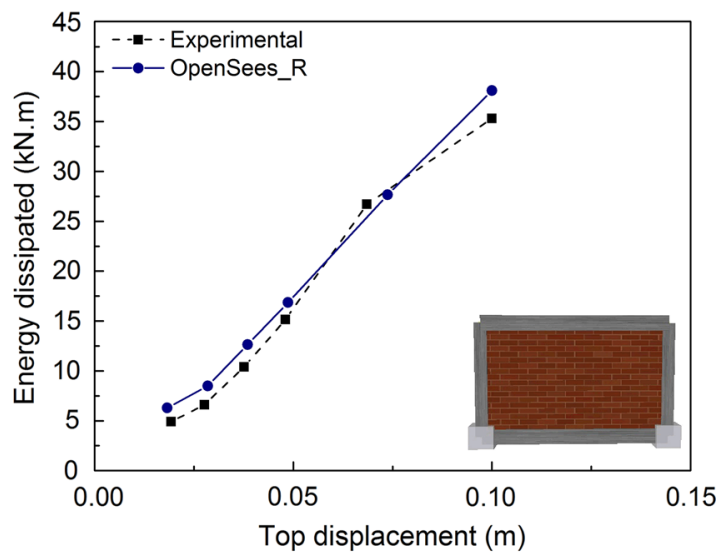

(d)

Fig. 8 a Hysteretic behaviour of the masonry infill wall, b base shear-top displacement, $\mathbf{c}$ shear-drift envelope and $\mathbf{d}$ energy dissipated results of experimental test and the numerical model

The RC frame was modelled using beam with hinges elements. The properties of the models ( $\mathrm{RC}$ frame and infill panel) were calibrated with test results from material specimens (Table 1).

The reference parameters adopted for the central element followed the proposed values by Zarnic and Gostic (1997c) and later modified by Dolsek and Fajfar (2008) which are based on recommendations from past researchers, experimental tests and are in accordance with the FEMA 356 (2000) recommendations, and the hysteretic curve of the central element is illustrated in Fig. 8a. The numerical model results were calibrated with the experimental results in terms of shear-top displacement (Fig. 8b), shear-drift envelopes (Fig. 8c) and energy 




Fig. 9 Buildings' plant disposition (in metres)

dissipated (Fig. 8d). The obtained results with the numerical model (OpenSees_R) are in good agreement with the experimental response in terms of shear-top displacement response (Fig. 8b, c) and energy dissipation (Fig. 8d) demonstrating the ability of the proposed model to simulate the global hysteretic response of infilled frames.

The base shear-top displacement envelope of the numerical model is $<5 \%$ higher in terms of base shear for the same top displacement values. The dissipated energy was determined (Fig. 8d), and the numerical model shows a good agreement with the experimental response, with $<5 \%$ of difference which is acceptable because it is a simplified model that is used to model the entire infill panel and its surrounding frame elements. In general, the OpenSees_R results are in good agreement with experimental results.

\section{Case studies}

With the aim of evaluating the influence of the masonry infill walls in the structural response of existing buildings when subjected to seismic loadings, two case studies will be studied. The buildings were designed in a project carried out by LNEC about structural design of structures submitted to seismic actions (Carvalho and Coelho 1984). The columns are spaced by $4 \mathrm{~m}$ in longitudinal direction and
$5 \mathrm{~m}$ in transversal direction with a storey height of $3 \mathrm{~m}$ and illustrated in Fig. 9.

The buildings have different number of storeys (four and eight), and three different dispositions of the infill panels were considered: bare frame (BF) model, full infill (INF) model and model without infill on the ground floor (SS) which are presented in Fig. 10a-c, respectively. The columns and beams' cross sections are presented in Figs. 11 and 12. More details about the reinforcement design can be found in Carvalho and Coelho (1984).

A 3D model was developed to simulate the buildings structural behaviour using the software program OpenSees (Mckenna et al. 2000). The RC elements were modelled using beam with hinges elements, and to simulate the materials, the Mander et al. (1988) and Menegotto and Pinto (1973) proposal were adopted, respectively.

The buildings under study were subjected to nonlinear dynamic analysis and, particularly, to one artificial earthquake that was been generated for a medium-/high-risk scenario in southern Europe (Varum 2003b) for different return periods as mentioned in Table 2. Hazard consistent time series of acceleration (with $15 \mathrm{~s}$ of duration) was artificially generated yielding a set of ten uniform hazard response spectra for increasing periods. Figure 13 illustrates the ground motion acceleration of seismic action for the return period of 2000 years.

\section{Nonlinear dynamic analysis results}

The maximum base shear results from the dynamic analysis for the two case studies are shown in Fig. 14. It can be observed that the presence of the infills increases the strength and stiffness of the buildings as expected. The base shear values of the eight-storey building are almost two times higher than the four-storey building. It is observed that the values for the SS models are very similar to the BF models, but with two times more initial stiffness.

The maximum drift observed in the structure is presented in Fig. 15 and is clear that the SS model is where the highest values are observed. The eight-storey SS building presented drift levels higher than the BF model after $0.3 \mathrm{~g}$.

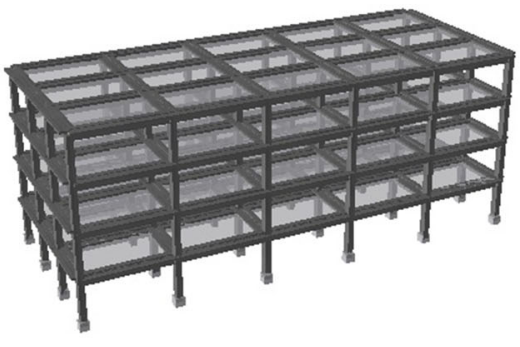

(a)

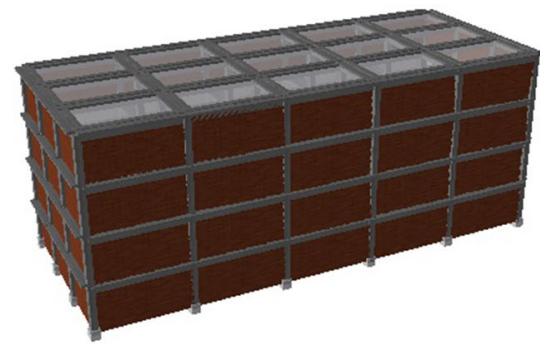

(b)

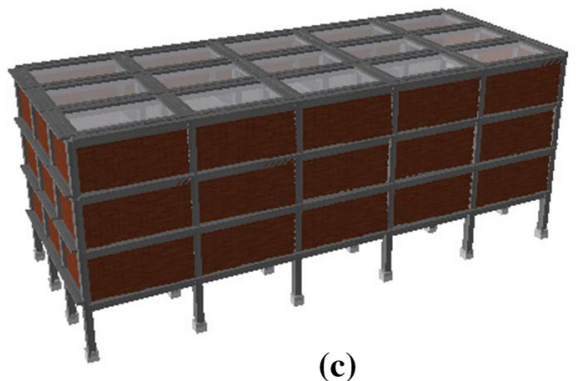

(c)

Fig. 10 a Bare frame (BF) model, b full infill (INF) model and c soft-storey (SS) model 


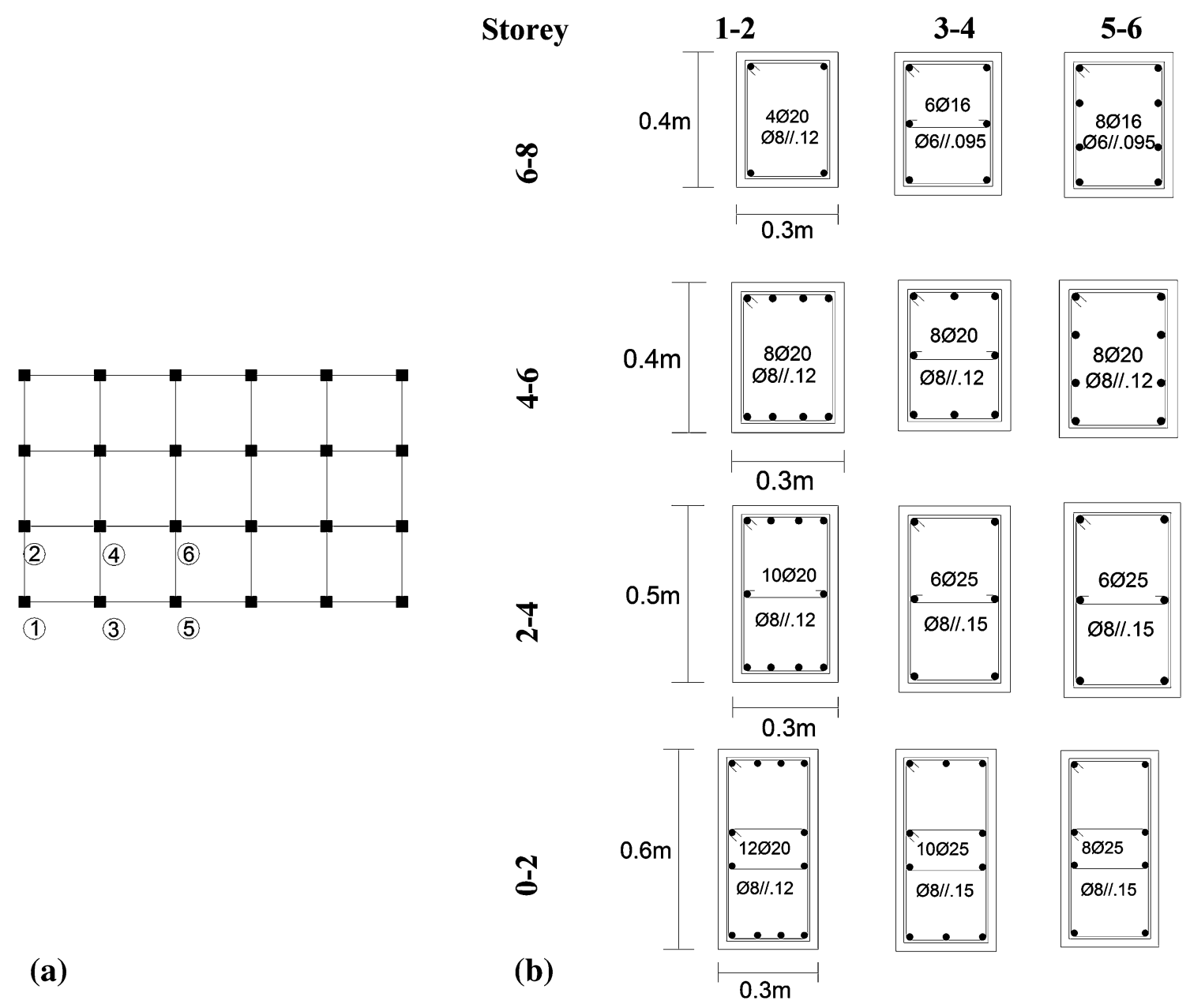

Fig. 11 a Columns' plant disposition, b columns' cross sections (in metres)

Localization of the beams

A

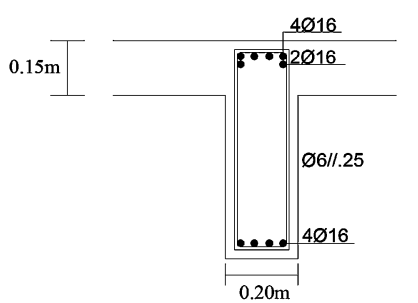

0-2

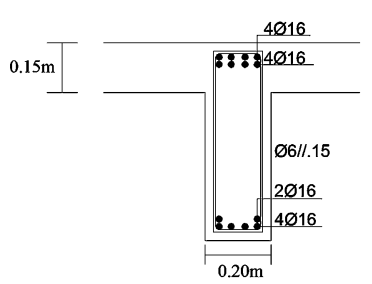

4-8

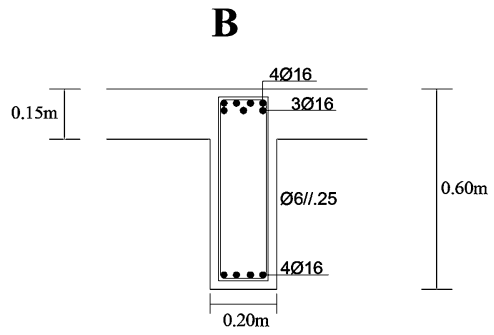

0-4

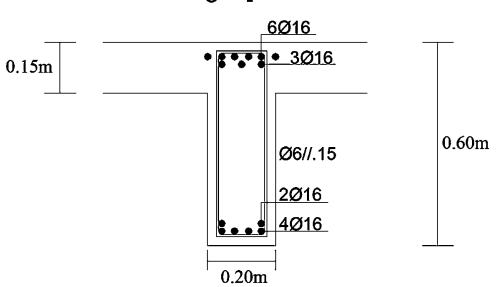

4-8

(b)

Fig. 12 a Beams' plant disposition, b columns' cross sections (in metres) 
Table 2 Peak ground acceleration and corresponding return period (RP)

\begin{tabular}{ll}
\hline RP (years) & Peak acceleration $\left(\mathrm{m} / \mathrm{s}^{2}\right)$ \\
\hline 73 & $0.889(0.09 \mathrm{~g})$ \\
100 & $1.060(0.11 \mathrm{~g})$ \\
170 & $1.402(0.14 \mathrm{~g})$ \\
300 & $1.796(0.18 \mathrm{~g})$ \\
475 & $2.180(0.22 \mathrm{~g})$ \\
700 & $2.543(0.26 \mathrm{~g})$ \\
975 & $2.884(0.29 \mathrm{~g})$ \\
1370 & $3.265(0.33 \mathrm{~g})$ \\
2000 & $3.728(0.38 \mathrm{~g})$ \\
3000 & $4.273(0.44 \mathrm{~g})$ \\
5000 & $5.036(0.51 \mathrm{~g})$ \\
9980 & $6.212(0.63 \mathrm{~g})$ \\
\hline
\end{tabular}

This fact highlights the vulnerability of this type of buildings, and the need to consider the infill walls participation since a significant number of buildings do not have masonry infill walls at the ground floor for architectural options.

It is observed that for both of the buildings, the maximum drift of INF model has lower values until approximately $0.3 \mathrm{~g}$ and after that the values increase until close to the BF model. For last, the maximum drift values of the eight-storey building with four-storey building are higher besides the BF model, where the values are lower for the eight-storey building.

\section{Conclusions}

The masonry infill walls' in-plane behaviour was investigated in order to have a deep knowledge about the interaction with the surrounding frames and their nonlinear behaviour during an earthquake. A brief state of art of existing macro-modellings and micro-modellings was performed. It was observed that the micro-models allow us to obtain more accurate results, but otherwise they need more computational requirements. The macro-models can reproduce, with a good agreement, the real behaviour of these non-structural elements with less computational requirement and time. One of the difficulties of the macromodels is the difficulty to represent infill panels with openings.

This study presents a simplified macro-model that simulates the nonlinear behaviour of the infill panels when subjected to in-plane actions and the respective application in the computer program OpenSees. This model, based on the Rodrigues et al. proposal, is adopted from the typical strut model considering the infill-surrounding frame interaction in both directions and is composed by four diagonal struts and a nonlinear central element that represent the nonlinear behaviour of the infills. A simplified procedure to determine the required parameters to define the model was presented followed by the validation of the proposed method with available experimental data.

This proposed model was calibrated with the results of one infilled single-storey experimental test that was

Fig. 13 Ground motion acceleration time history for the 2000-year RP



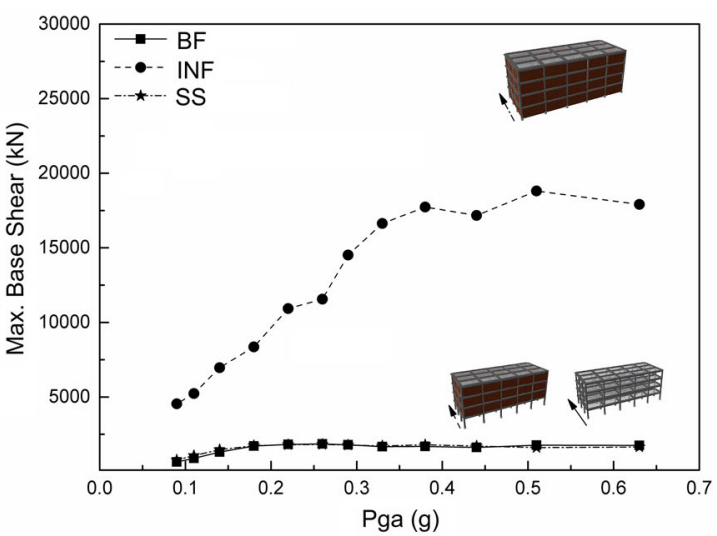

(a)

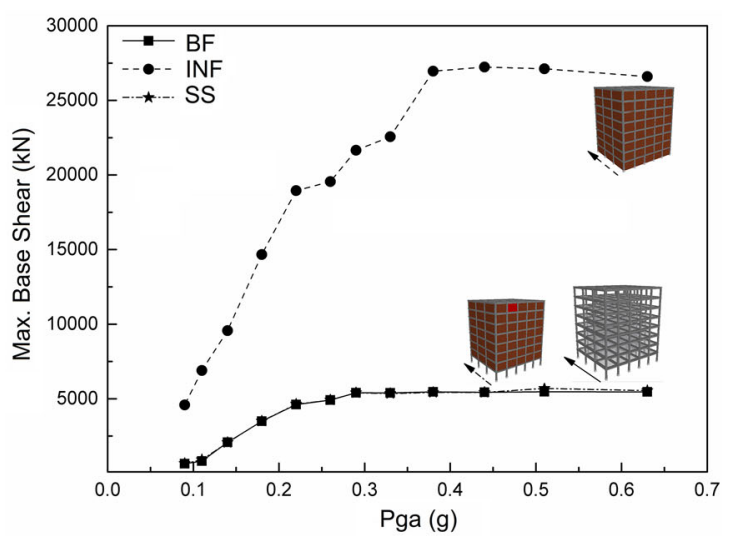

(b)

Fig. 14 Max base shear results. a Four-storey building, b eight-storey building 


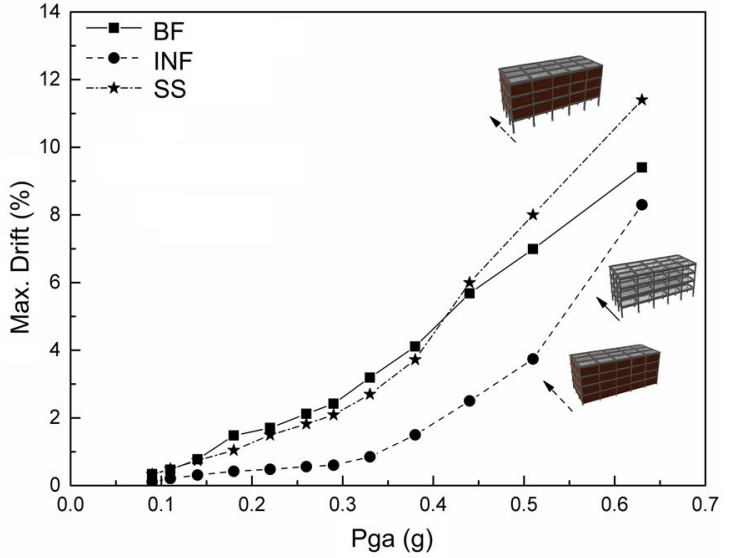

(a)

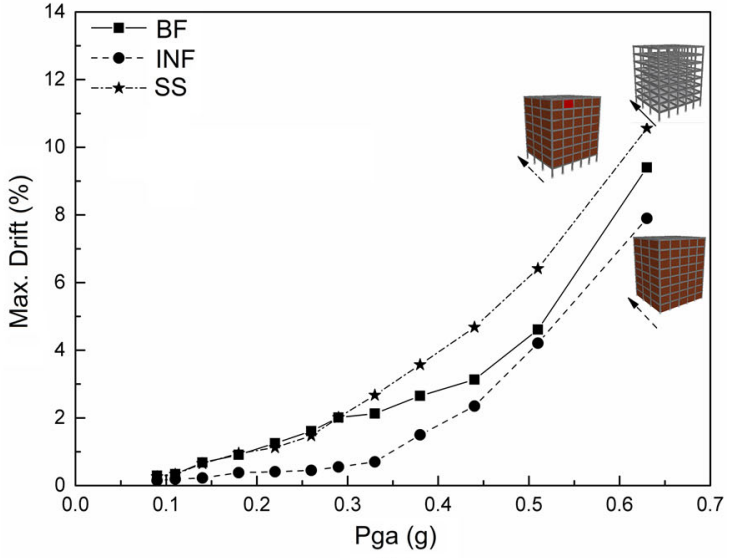

(b)

Fig. 15 Max drift results. a Four-storey building, b eight-storey building

submitted to cyclic in-plane loads performed by Pires. The numerical results show a good agreement in terms of sheartop displacement and energy dissipation. The results show that this modelling strategy adopted in OpenSees can be useful for anyone since the definition of the parameters that are necessary to define the infill wall is suggested by different authors and international codes recommendations, which according to the calibration results represents the experimental infills' behaviour with a good accuracy.

Finally, two RC buildings with masonry infill walls and different number of storeys were subjected to nonlinear dynamic analysis for three different situations: bare frame, full infill and soft storey. It was observed that the infills increased the initial stiffness and maximum strength and that the maximum drift in the buildings occurs always in the model without infills at the ground floor.

Acknowledgments This research was developed under financial support provided by "FCT-Fundação para a Ciência e Tecnologia", Portugal, namely through the research project PTDC/ECM/122347/ 2010 - RetroInf-Developing Innovative Solutions for Seismic Retrofitting of Masonry Infill Walls.

Open Access This article is distributed under the terms of the Creative Commons Attribution 4.0 International License (http:// creativecommons.org/licenses/by/4.0/), which permits unrestricted use, distribution, and reproduction in any medium, provided you give appropriate credit to the original author(s) and the source, provide a link to the Creative Commons license, and indicate if changes were made.

\section{References}

Asteris P, Cotsovos D (2012) Numerical investigation of the effects of infill walls on the structural response of RC frames. Open Constr Build Technol J 6:164-181

Asteris P, Cotsovos D, Chrysostomou C, Mohebkhah A, Al-Chaar G (2013) Mathematical micromodelling of infilled frames: state of the art. Eng Struct 56:1905-1921
Asteris P, Tzamtzis A (2003) On the use of a regular yield surface for the analysis of unreinforced masonry walls. Electron J Struct Eng 3:23-42

Carvalho E, Coelho E (1984) Análise Sísmica de estruturas de edifícios segundo a nova regulamentação - Análise Estrutural de um conjunto de 22 edifícios, vol II. Lisboa, Portugal

Chrystomou C (1991) Effects of degrading infill walls on the nonlinear seismic response two-dimensional steel frames. Cornel University, Ithaca

Costa AA, Ferreira M, Oliveira C (2010) O grande sismo de Sichuan: impactos e lições para o futuro. Paper presented at the Sísmica $2010-8^{\circ}$ Congresso de Sismologia e Engenharia Sísmica, Aveiro

Crisafulli F (1997a) Seismic behavior of reinforced concrete structures with masonry infills. University of Canterbury, Canterbury

Crisafulli F (1997b) Seismic behaviour of reinforced concrete structures with masonry infills. University of Canterburry, Canterbury

Crisafulli F, Carr A (2007) Porposed macro-model for the analysis of infilled frame structures. Bull N Z Soc Earthq Eng 40:69-77

Davis R, Krishnan P, Menon D, Prasad A (2004) Effect of infill stiffness on seismic performance of multi-storey RC framed buildings in India. Paper presented at the 13th world conference on earthquake engineering, Vancouver, BC, Canada

Dhanasekhar M, Page A (1986) The influence of brick masonry infill properties on the behavior of infilled frames. In: ICE, pp 593-605

Dolsek M, Fajfar P (2001) Soft Storey effects in uniformly infilled reinforced concrete frames. J Earthq Eng 5:1-12

Dolsek M, Fajfar P (2002) Mathematical modeling of an infilled RC frame structure based on the results of pseudo-dynamic tests. Earthq Eng Struct Dyn 31:1215-1230

Dolsek M, Fajfar P (2008) The effect of masonry infills on seismic response of a four storey reinforced concrete frame-a probabilistic assessment. Eng Struct 30:1991-2001

El-Dakhakhni WW, Elgaaly M, Hamid AA (2003) Three-strut model for concrete masonry-infilled steel frames. J Struct Eng 129:177-185

FEMA356 (2000) Prestandard and commentary for the seismic rehabilitation of buildings. Federal Emergency Management Agency, Washington, DC

Flanagan R, Bennet R (1999) Arching of masonry infilled frame: comparison of analytical methods. Pract Period Struct Des Constr 4:105-110 
Furtado A (2013) Avaliação de soluções de reforço para edificios com $\mathrm{r} / \mathrm{c}$ vazado. Universidade de Aveiro

Furtado A, Rodrigues H, Varum H, Costa A (2014) Assessment and strengthening strategies of existing RC buildings with potential soft-storey response. In: 9th international masonry conference (IMC), Portugal

Holmes M (1961) Steel frames with brickwork and concrete filling. Proc Inst Civ Eng 2 Res Theory 19:473-478

Kakaletsis D, Karayannis C (2008) Influence of masonry strenght and openings on infilled R/C frames under cycling loading. J Earthq Eng 12:197-221

Klingler R, Bertero V (1978) Earthquake resistance of infilled frames. J Struct Div 104:973-989

Koutromanos I, Stravidris A, Shing P, Quenneville J (2011) Numerical modelling of masonry-infilled RC frames subjected to seismic loads. Comput Struct 89:1026-1037

Liauw T, Kwan K (1984) Nonlinear behavior of non-integral infilled frames. Comput Struct 18:551-560

Lofti H, Shing P (1991) An appraisal of smeared crack models for masonry shear wall analysis. Comput Struct 41:413-425

Lourenço P (2002) Computations on historic masonry structures. Prog Struct Eng Mater 4:301-319

Lourenço P, Rots J (1997) Multisurface interface model for analysis of masonry structures. J Eng Mech 123:660-668

Mainstone RJ (1974) Supplementary note on the stiffness and strength of infilled frames. Building Research Station, UK, CP 13/74

Mainstone J, Weeks G (1970) The influence of bounding frame on the racking stiffness and strength of brick walls. In: 2nd international brick masonry conference, Watford

Mallick D, Seven R (1968) Dynamic characteristics of infilled frames. ICE Proc 39(2):261-287

Mander J, Priestleyand M, Parks R (1988) Theoretical stress-strain model for confined concrete. J Struct Eng 114:1804-1826

Manfredi G, Ricci P, Verderame G (2012) Influence of infill panels and their distribution on seismic behavior of existing reinforced concrete buildings. Open Constr Build Technol J 6:236-253

Manzouri T (1995) Nonlinear finite element analysis and experimental evaluation of retrofitting techniques for unreinforced masonry structures. University of Colorado-Boulder, Boulder

Mckenna F, Fenves G, Scott M, Jeremic B (2000) Open system for earthquake engineering simulation (OpenSees). Berkley, CA

Mehrabi A, Shing P (1997) Finite-element modelling of masonryinfilled RC frames. J Struct Eng 123:604-613

Menegotto M, Pinto P (1973) Method of analysis for cyclically loaded reinforced concrete plane frames including changes in geometry and non-elastic behaviour of elements under combined normal force and bending. Lisbon, Portugal

Mosalam K, Ayala G, White R, Roth C (1997) Seismic fragility of LRC frames with and without masonry infill walls. J Earthq Eng 1:693-720

Oliveira D, Lourenço P (2004) Implementation and validation of a constitutive model for the cyclic behaviour of interface elements. Comput Struct 82:1451-1461
Pires F (1990) Influência das paredes de alvenaria no comportamento de estruturas de betão armado sujeitas a ações horizontais. LNEC

Polyakov S (1960) On the interaction between masonry filler walls and enclosing frame when loading in the plane of the wall. Transl Earthq Eng E2:36-42

Rodrigues H (2005) Desenvolvimento e calibração de modelos numéricos para a análise sísmica de edifícios. Universidade do Porto

Rodrigues H, Varum H, Costa A (2010) Simplified macro-model for infill masonry panels. J Earthq Eng 14:390-416

Romão X, Costa AA, Paupério E, Rodrigues H, Vicente R, Varum H, Costa A (2013) Field observations and interpretation of the structural performance of constructions after the 11 May 2011 Lorca earthquake. Eng Fail Anal 34:670-692

Saneinejad A, Hobbs B (1995) Inelastic design of infilled frames. J Struct Eng 121:634-650

Schmidt T (1989) An approach of modelling masonry infilled frames by the f.e. method and a modified equivalent strut model. Annu J Concr Concr Struct 4:171-180

Shing P et al. (2009) Seismic performance of non-ductile RC frames with brick infill. Paper presented at the improving the seismic performance of existing buildings and other structures, ATC/S EI

Smith S (1962) Lateral stiffness of infilled frames. J Struct Div $88: 183-199$

Smyrou E, Blandon C, Antoniou S, Pinho R, Crisafulli F (2011) Implementation and verification of a masonry panel model for nonlinear dynamic analysis of infilled RC frames. Bull Earthq Eng 9:1519-1534

Stravidris A, Shing P (2010) Finite-element modelling of nonlinear behavior of masonry infilled RC frames. J Struct Eng 136:285-296

Syrmakesis C, Vratsanou V (1986) Influence of infill walls to RC frames response. In: 8th European conference on earthquake engineering, Istanbul, Turkey, pp 47-53

Varum H (2003a) Seismic assessment, strengthening and repair of existing buildings. Universidade de Aveiro

Varum H (2003b) Seismic assessment, strengthening and repair of existing buildings. Universidade de Aveiro

Zarnic R, Gostic S (1997a) Masonry infilled frames as an effective structural sub-assemblage. In: Fajfar P, Krawinkler H (eds) Seismic design methodologies for the next generation of codes. pp 335-346

Zarnic R, Gostic S (1997b) Masonry infilled frames as an effective structural sub-assemblage. In: International workshop, Bled, Slovenia

Zarnic R, Gostíc S (1997c) Masonry infilled frames as an effective structural sub-assemblage. Paper presented at the seismic design methodologies for the next generation of codes, Rotterdam, Balkema

Zarnic R, Tomazevic M (1988) An experimentally obtained method for evaluation of the behavior of masonry infilled RC frames. In: 9th world conference on earthquake engineering, pp 163-168 